\title{
Incidence of Bakanae disease of basmati rice in south-western part of Punjab and its management
}

\author{
GURMAIL SINGH SANDHU* AND N.S. DHALIWAL \\ Krishi Vigyan Kendra, SRI MUKTSAR SAHIB (PUNJAB) INDIA
}

\section{ARITCLE INFO}

Received : 09.01 .2016

Accepted : 26.03.2016

\section{KEY WORDS :}

Basmati rice, Bakanae disease, Foot rot disease, Punjab

*Corresponding author:

Email: gurmailent@pau.edu

\begin{abstract}
Basmati rice is an important cash crop of India, being recognized at international level for its quality and aroma. Bakanae/foot rot disease is becoming a limiting factor in its cultivation in southwestern parts of Punjab. A survey was conducted during Kharif 2014 in different blocks of Sri Muktsar Sahib District of Punjab to acquaint with the factor affecting disease incidence. Disease was recorded in all the basmati growing fields and up to 10 per cent incidence was recorded on different aromatic rice cultivars. Pusa Basmati 1401 was observed more susceptible followed by Pusa Basmati 1121 and Pusa Basmati 1509.Basmati crop raised at recommended period showed lower disease incidence than early transplanted crop. Higher disease incidence was observed in fields where seed was purchased from private seed companies than seed from State Agricultural University. The recommended technology to manage this disease i.e. seed soaking in pesticides solution containing carbendazim 50 WP @ 0.2 per cent + Streptocycline 0.01 per cent (one g) for $12 \mathrm{hrs}$ followed by seedling root dip in carbendazim $50 \mathrm{WP}(0.2 \%)$ for $6 \mathrm{hrs}$ was demonstrated at selected farmers' field during Kharif 2015. The results showed that seed treatment with carbendazim @ $2.0 \mathrm{~g} / \mathrm{kg}$ alone (farmers' practice) was not effective. The disease incidence in demonstrated plots was less as compared to farmers' practice. The grain yield and net returns were also higher in demonstrated plots.
\end{abstract}

How to view point the article : Sandhu, Gurmail Singh and Dhaliwal, N.S. (2016). Incidence of Bakanae disease of basmati rice in south-western part of Punjab and its management. Internat. J. Plant Protec., 9(1) : 353-357. 